\title{
RELATIONSHIP OF FACTOR WITH EARLY PREGNANCY IN WORKING AREA PUBLIC HEALTH CENTER
}

\author{
Evi Hasnita \\ STIKes Fort De Kock, Bukittinggi \\ email: evi.hasnita@yahoo.co.id
}

Submitted: 05-12-2016, Reviewer: 07-12-2016, Accepted: 07-12-2016

\begin{abstract}
According to the Bureau of Statistics survey in 2012 in Indonesia was 48 / 1,000 pregnancies at the age of 15-19, while in 2007 was $8.5 \%$ of pregnancies at age $<20$ years. Public health center Guguk Panjang 20\% of women with risk pregnancies with child-bearing age $<20$ years. This study aims to determine the factors associated with Pregnancy Early in Puskesmas Guguk Panjang.This type of research is descriptive analytic with cross sectional approach. The population in the study were all pregnant women in Public health center Guguk Panjang. Retrieval using random sampling techniques to obtain 100 respondents. Data collected by using a questionnaire. Data analysis included univariate and bivariate, using chi-square test. The results of the bivariate, showed that there is a relationship of education $(p=0.003, O R=3.857)$, the economy $(p=0.018, O R=2.893)$, behavior $(p=0.003, O R=3.821)$, sociocultural $(p=0.01, O R=3.261)$ and the media $(p=0.011$, $O R=4.030)$ with a teen pregnancy. It can be concluded that education, economic status, behavioral, social, cultural, and media associated with teen pregnancy. For the expected role of the various parties to raise public awareness, especially young women, the risks of pregnancy at an early age so that young women are not affected by various factors that may increase the risk of teen pregnancy.
\end{abstract}

Keywords : Behavioral, early pregnancy

\begin{abstract}
ABSTRAK
Menurut Survey Badan Statistik Tahun 2012 di Indonesia tercatat 48/1.000 kehamilan pada usia 15 - 19 sedangkan tahun 2007 tercatat 8,5\% kehamilan pada usia < 20 tahun. Puskesmas Guguk Panjang 20\% ibu dengan kehamilan beresiko dengan usia hamil $<20$ tahun. Penelitian ini bertujuan untuk mengetahui faktor-faktor yang berhubungan dengan Kehamilan Usia Dini di Wilayah Kerja Puskesmas Guguk Panjang Tahun 2016.

Jenis penelitian ini adalah deskriptif analitik dengan pendekatan cross sectional. Populasi pada penelitian adalah seluruh ibu hamil di wilayah kerja Puskesmas Guguk Panjang. Pengambilan menggunakan teknik random sampling sehingga didapatkan 100 respoden. Data dikumpulkan dengan cara menggunakan kuesioner. Analisis data meliputi analisis univariat dan analisis bivariat menggunakan uji chi-square.Hasil analisis bivariat menunjukkan bahwa ada hubungan pendidikan ( $p=0,003$, OR =3,857), ekonomi ( $p=0,018$, OR =2,893), perilaku $(p=0,003$, OR $=3,821)$, sosial budaya $(p=0,01, O R=3,261)$ dan media massa $(p=0,011, O R=4,030)$ dengan kehamilan usia dini. Dapat disimpulkan pendidikan, status ekonomi, perilaku, sosial budaya, dan media massa berhubungan dengan kehamilan usia dini. Diharapkan peran berbagai pihak dalam meningkatkan pemahaman masyarakat, khususnya remaja putri. agar remaja putri tidak terpengaruh oleh berbagai faktor yang dapat meningkatkan resiko kehamilan usia dini.
\end{abstract}

Kata Kunci : Kehamilan usia dini, perilaku 


\section{PENDAHULUAN}

Organisasi kesehatan dunia (WHO) tahun 2012 menunjukkan bahwa sebanyak 16 juta kelahiran terjadi pada ibu yang berusia 15-19 tahun atau $11 \%$ dari seluruh kelahiran di dunia yang mayoritas (95\%) terjadi di negara sedang berkembang. Di Amerika Latin dan Karibia, 29\% wanita muda menikah saat mereka berusia 18 tahun. Prevalensi tertinggi kasus pernikahan usia dini tercatat di Nigeria (79\%), Kongo (74\%), Afganistan (54\%), dan Bangladesh (51\%) (WHO, 2012).

Di Indonesia pernikahan dini 15$20 \%$ dilakukan oleh pasangan baru. Biasanya pernikahan dini dilakukan pada pasangan muda yang rata-rata umurnya 18 , 19, dan 20 tahun. UU Perkawinan No 1 1974 dengan usia kawin perempuan 16 tahun menyebabkan perkawinan sah di usia remaja mengalami peningkatan. Temuan Biro pusat statistic 1980 bahwa $6,40 \%$ perempuan menikah pertama kali pada usia 16 tahun, 23,89\% usia 17-18 tahun dan $39,70 \%$ menikah pada usia 19 tahun (Sugiharta, 2004).

Survei Badan Pusat Statistik (BPS) Indonesia tahun 2012 menemukan bahwa angka kehamilan remaja usia 1519 tahun mencapai 48 dari 1.000 kehamilan. Angka kematian ibu dan bayi yang pada pertengahan 2013 mencapai 359 untuk tiap 100.000 kelahiran hidup, dengan angka kematian bayi 32 per 1.000 kelahiran hidup. Dibandingkan dengan negara ASEAN lainnya, Indonesia menempati urutan ke-8 terkait tingginya angka kematian pada kasus ini (Badan Pusat Statistik, 2012).

Menurut Badan Koordinasi

Keluarga Berencana Nasional (BKKBN) usia untuk hamil dan melahirkan adalah 20 sampai 30 tahun, lebih atau kurang dari usia tersebut adalah berisiko. Kesiapan seorang perempuan untuk hamil dan melahirkan atau mempunyai anak ditentukan oleh kesiapan dalam tiga hal, yaitu kesiapan fisik, kesiapan mental, emosi, psikologis, dan kesiapan sosial ekonomi (BKKBN, 2014).

Sedangkan menurut hasil survei Badan pusat statistik tahun 2012 mengungkapkan angka kehamilan remaja pada usia 15-19 tahun mencapai 48 dari 1.000 kehamilan. Tingginya angka kehamilan remaja ini menjadi salah satu penyumbang jumlah lematian ibu ditanah air. Dari survey dasar kesehatan remaja 2007, di dapatkan bahwa pengetahuan remaja tentang kesehatan reproduksi masih rendah, yaitu sebanyak 21 persen remaja perempuan tidak mengetahui perubahan fisik remaja lelaki puber. Bahkan, hanya 29 persen remaja perempuan dan 32 persen remaja lelaki mengetahui seorang perempuan berpeluang hamil pada pertengahan siklus periode haid (BKKBN,2014).

Data Survei Kesehatan Ibu dan Anak tahun 2000 menunjukkan median umur kehamilan pertama di Indonesia adalah 18 tahun, di mana sebanyak 46\% perempuan mengalami kehamilan pertama di bawah usia 20 tahun. Padahal hal itu sangatlah berbahaya. Remaja merupakan kelompok yang tingkat komplikasinya lebih tinggi selama kehamilan dan persalinan. Dari sudut pandang kesehatan obstetric, kehamilan dan persalinan pada usia remaja memberikan resiko komplikasi yang mungkin terjadi pada ibu dan anak seperti anemia, preeclampsia, eklampsia, abortus, partus prematurus, kematian perinatal, perdarahan dan tindakan operatif obstertic lebih sering dibandingkan dengan kehamilan pada golongan usia 20 tahun keatas (sugiharta, 2004).

Data Survei Demografi dan Kesehatan Indonesia (SDKI) tahun 2007 menunjukkan bahwa angka kehamilan dan kelahiran pada usia muda ( $<20$ tahun) masih sekitar $8,5 \%$ (BKKBN,2008). 
Sebuah survei di Jawa Barat pada tahun 2008 juga mengungkapkan bahwa remaja putri menikah pada usia di bawah 16 tahun sebesar $16 \%$ dan proporsi kehamilan remaja mencapai 4,1\% (Zuhri, 2010).

Berdasarkan data survey awal di puskesmas guguk panjang terdapat 2.845 ibu hamil dan terdapat $20 \%$ bumil resiko tinggi, setelah melakukan wawancara terhadap 10 orang ibu hamil 6 diantaranya berumur kurang dari 20 tahun dan dari 6 orang ibu hamil yang berumur kurang dari 20 tahun beberapa diantaranya mengaku tidak mengetahui faktor resiko dan dampak kehamilan usia dini bagi ibu maupun janin yang dikandungnya.

\section{METODE PENELITIAN}

Jenis penelitian ini adalah Deskriptif Analitik dengan desain penelitian cross sectional. Penelitian ini dilakukan di Puskesmas Guguk Panjang Bukitting Penelitian ini merupakan penelitian deskriptif analitik yaitu desain penelitian yang menjelaskan tentang gambaran dari variabel yang diteliti, juga menganalisis hubungan antara variabel dependen dan variabel independendengan desain penelitian desain cross sectional. Dimana variabel independen adalah tingkat pengetahuan ibu, pendidikan ibu,tingkat ekonomi, sosial budaya, media massa, sedangkan variabel dependennya adalah kehamilan usia dini yang diambil dalam waktu yang bersamaan.

Penelitian ini dilakukan pada Bulan Mei - Juli 2016. Populasi dalam penelitian ini adalah Seluruh ibu hamil dengan teknik sampel adalah random sampling dengan jumlah sampel sebanyak 100 orang. Data dikumpulkan melalui kuesioner dan dari data sekunder Puskesmas. Kemudian data di analisis dengan uji statistik chi-square dengan derajat kepercayaan $\alpha=0,05$.

\section{HASIL DAN PEMBAHASAN}

Hasil penelitian yang dilakukan di Puskesmas Guguk Panjang Bukittinggi Tahun 2016 tentang faktor-faktor yang berhubungan dengan kejadian kehamilan usia dini di wilayah kerja puskesmas guguk panjang tahun 2016. Data dianalisis secara univariat dan bivariat. Adapun hasil dari penelitian ini adalah sebagai berikut :

\section{Hasil Univariat a.Pengetahuan}

Tabel 1

Distribusi Frekuensi Responden Berdasarkan Pendidikan di Wilayah Kerja Puskesmas Guguk Panjang

\begin{tabular}{clcc}
\hline No & Pendidikan & f & \% \\
\hline 1. & Rendah & 40 & 40 \\
2. & Tinggi & 60 & 60 \\
\hline & Jumlah & 100 & 100
\end{tabular}

Berdasarkan tabel 1 diketahui bahwa dari 100 orang responden, terdapat lebih dari sebahagian yaitu sebanyak 60 orang $(60 \%)$ responden berpendidikan tinggi. Pengetahuan adalah hasil "tahu" dan ini terjadi setelah orang melakukan penginderaan terhadap suatu objek tertentu. Penginderaan itu terjadi melalui panca indera manusia yakni indera penglihatan, pendengaran, penciuman, rasa dan raba. Sebagian besar penginderaan manusia diperoleh melalui mata dan telinga. Pengetahuan kognitif merupakan doamin yang sangat penting dalam membentuk tidakan seseorang. Perilaku yang didasarkan pengetahuan, kesadaran, dan sikap positif lebih langgeng dari pada perilaku yang tidak didasarkan oleh pengetahuan (Notoatmodjo, 2010).

Pengetahuan yang baik sangat mempengaruhi pola pikir seseorang, karena semakin tinggi pengetahuan seseorang semakin tinggi pula kemampuan dan kesadaran mereka dalam menerima informasi serta menerapkannya dengan mudah dalam kehidupan sehari- hari.

Hasil penelitian menunjukkan bahwa lebih dari sebahagian $(60 \%)$ ibu hamil di wilayah kerja Puskesmas Guguk Panjang dengan tingkat pendidikan tinggi, yaitu ibu dengan tingkat pendidikan formal minimal hingga tingkat SMA/ sederajat. Tingkat pendidikan ibu paling banyak adalah SMA yaitu sebanyak 60 orang (60\%), SMP/ sederajat 24 orang $(24 \%)$ dan $\mathrm{SD} /$ sederajat sebanyak 16 orang (16\%) serta tidak ditemukan ibu hamil yang melanjutkan pendidikan hingga tingkat perguruan tinggi.

Menurut asumsi peneliti di wilayah kerja Puskesmas Guguk Panjang, pada 
umumnya masyarakatnya telah menempuh jenjang pendidikan hingga tingkat SMA/ sederajat, khususnya pada ibu hamil, dimana pada penelitian ini ditemukan lebih dari sebahagian ibu hamil dengan tingkat pendidikan formal hingga SMA/ sederajat. Kondisi ini menunjukkan bahwa tingkat kesadaran masyarakat akan pentingnya pendidikan sudah baik, sehingga sebagian besar masyarakat akan berusaha untuk melanjutkan pendidikannya minimal hingga tingkat SMA/ sederajat dan bahkan hingga jenjang perguruan tinggi.

\section{b. Perilaku}

Tabel 2

Distribusi Frekuensi Responden Berdasarkan Perilaku di Wilayah Kerja Puskesmas Guguk Panjang

\begin{tabular}{rccc}
\hline No & Perilaku & f & \% \\
\hline 1. & Negatif & 52 & 52 \\
2. & Positif & 48 & 48 \\
\hline & Jumlah & 100 & 100
\end{tabular}

Berdasarkan tabel 2 diketahui bahwa dari 100 orang responden, terdapat lebih dari sebahagian yaitu sebanyak 52 orang $(52 \%)$ responden dengan perilaku negatif.

Perilaku adalah suatu kegiatan atau aktifitas yang dilakukan manusia baik itu perilaku tertutup (covert behavior) maupun perilaku terbuka (over behavior) (Notoatmodjo, 2007).

Hasil penelitian menunjukkan bahwa lebih dari sebahagian (52\%) responden dengan kategori perilaku negatif yaitu perilaku yang beresiko terhadap kehamilan di usia dini. Sedangkan sisanya sebanyak $48 \%$ adalah ibu hamil dengan kategori perilaku positif.

Menurut asumsi peneliti di Wilayah Kerja Puskesma Guguk Panjang masih banyak ditemukan masyarakatnya yang berperilaku negatif yaitu perilaku yang beresiko untuk menjalani kehamilan di usia dini, dimana masih banyak ditemukan masyarakatnya khususnya remaja yang memiliki perilaku yang beresiko terhadap kehamilan usia dini, yaitu perilaku seks pada usia dini, seperti berpacaran, berpelukan atau bahkan berhubungan seksual di usia yang cenderung terlalu muda.

\section{c. Sosial Budaya}

Tabel 3

Distribusi Frekuensi Responden Berdasarkan Sosial Budaya di Wilayah Kerja Puskesmas Guguk Panjang

\begin{tabular}{cccc}
\hline No & $\begin{array}{c}\text { Sosial } \\
\text { Budaya }\end{array}$ & f & \% \\
\hline 1. & Tidak & 38 & 38 \\
2. & Baik Baik & 62 & 62 \\
\hline & Jumlah & 100 & 100
\end{tabular}

Berdasarkan tabel 3 diketahui bahwa dari 100 orang responden, terdapat lebih dari sebahagian yaitu sebanyak 62 orang (62\%) responden dengan sosial budaya baik.

Sosial budaya yang mengatur, menafsirkan dan mendefisinisikan tentang usia untuk kehamilan yaitu bagaimana cara pandang dan kebiasaan masyarakat untuk mengatur usia yang tepat untuk menjalani kehamilan bagi perempuan, karena sosial budaya adalah keseluruhan sistem gagasan, tindakan dari hasil karya manusia dalam rangka membangun kehidupan masyarakat yang dijadikan milik dari manusia dengan belajar (Sudarman, 2008).

Hasil penelitian menunjukkan bahwa lebih dari sebahagian (62\%) ibu hamil dengan lingkungan sosial budaya positif, yaitu lingkungan sosial budaya yang memberikan nilai-nilai dan norma yang positif terhadap perkembangan dan perilaku masyarakat, khususnya norma yang mengatur tentang kehamilan usia dini.

Menurut asumsi peneliti pada dasarnya sosial budaya masyarakat di Wilayah Kerja Puskesmas tentang kehamilan usia dini adalah baik, dimana secara harfiah masyarakat menyadari bahwa kehamilan pada usia kurang dari 20 tahun tidaklah baik karena wanita yang hamil tentulah harus berkeluarga dan di wilayah kerja Puskesmas Guguk Panjang masyarakatnya telah menyadari bahwa pada usia tersebut masih terlalu dini untuk menjalani bahtera rumah tangga, hamil dan mengurus keluarga sehingga beresiko terhadap kejadian perceraian.

\section{d. Media Massa}

Tabel 4

Distribusi Frekuensi Responden Berdasarkan Pengaruh Media Massa di Wilayah Kerja Puskesmas Guguk Panjang 


\begin{tabular}{|c|c|c|c|}
\hline No & Media Massa & $\mathbf{f}$ & $\%$ \\
\hline 1. & Terpengaruh & 75 & 75 \\
\hline 2. & Tidak Terpengaruh & 25 & 25 \\
\hline
\end{tabular}

Berdasarkan tabel 4 diketahui bahwa dari 100 orang responden, terdapat sebagian besar yaitu sebanyak 75 orang (75\%) responden yang beresiko terpengaruh dari media massa.

Media massa adalah sarana/alat untuk menyampaikan informasil, gagasan, iklan, pendidikan, dan hiburan kepada masyarakat luas. Media massa adalah alat yang digunakan dalam penyampaian pesanpesan dari sumber kepada khalayak (menerima) dengan menggunakan alatalat komunikasi mekanis seperti surat kabar, film, radio, TV (Cangara, 2002). Media massa adalah alat-alat dalam komunikasi yang bisa menyebarkan pesan secara serempak, cepat kepada audience yang luas dan heterogen. Kelebihan media massa dibanding dengan jenis komunikasi lain adalah ia bisa mengatasi hambatan ruang dan waktu. Bahkan media massa mampu menyebarkan pesan hampir seketika pada waktu yang tak terbatas (Nurudin, 2007).

Hasil penelitian ini sejalan dengan penelitian yang telah dilakukan oleh Murti (2008) dengan judul Hubungan antara frekuensi paparan pornografi melalui media massa dengan tingkat perilaku seksual pada siswa SMU Muhammadiyah 3, didapatkan hasil bahwa $50,7 \%$ remaja dengan paparan tinggi terhadap pornografi melalui media massa.

Menurut asumsi peneliti pada saat ini media massa memberikan pengaruh yang tinggi terhadap setiap aspek kehidupan masyarakat, terutama pada kelompok usia muda, dimana dengan kemajuan ilmu pengetahuan dan teknologi hampir seluruh lapisan masyarakat memiliki akses yang mudah terhadap kebutuhan informasi, terutama informasi yang disediakan di televisi dan internet.

\section{Hasil Bivariat}

\section{a Hubungan Pendidikan dengan Kehamilan Usia Dini}

Tabel 5
Hubungan Pendidikan dengan Kehamilan Usia Dini di Wilayah Kerja Puskesmas Guguk Panjang

\begin{tabular}{|c|c|c|c|c|c|c|c|c|c|}
\hline \multirow[t]{3}{*}{ No } & \multirow{3}{*}{$\begin{array}{c}\text { Pendidi } \\
\text { kan }\end{array}$} & \multicolumn{6}{|c|}{ Kehamilan Usia Dini } & \multirow{2}{*}{$\begin{array}{c}\text { pv } \\
\text { alu } \\
\text { e }\end{array}$} & \multirow{2}{*}{$\begin{array}{r}\text { OR } \\
(95 \% \text { CI })\end{array}$} \\
\hline & & \multicolumn{2}{|c|}{ Ada } & \multirow{2}{*}{$\begin{array}{l}\text { Tid } \\
\text { ak }\end{array}$} & \multicolumn{3}{|c|}{ Total } & & \\
\hline & & $\mathrm{n}$ & $\%$ & & $\%$ & $\mathrm{~N}$ & $\%$ & & \\
\hline 1 & Rendah & 27 & 67, & 13 & 32, & 40 & 100 & 0,0 & $3,857(1,6529,00)$ \\
\hline \multirow[t]{3}{*}{2} & Tinggi & 21 & 5 & 39 & 5 & 60 & 100 & 03 & \\
\hline & & & 35 & & 65 & & & & \\
\hline & Jumlah & 48 & 48 & 52 & 52 & 100 & 100 & & \\
\hline
\end{tabular}

Berdasarkan tabel 5 diketahui bahwa hubungan tingkat pendidikan dengan pernikahan dari 40 orang responden berpendidikan rendah, usia dini dengan nilai $\mathrm{p}=0,000$ dan $\mathrm{OR}=9,821$. lebih dari sebahagian $(67,5 \%)$ responden dengan Dan penelitian yang telah dilakukan oleh Nguyen kehamilan usia dini. Sedangkan dari 60 orang (2016) dengan judul Prevalence and Factors responden, kurang dari sebahagian (35\%) Associated with Teen Pregnancy in Vietnam: responden dengan kehamilan usia dini. Hasil Results from Two National Surveys didapatkan analisis statistik menunjukkan bahwa ada hubungan hasil bahwa ada hubungan pendidikan dengan antara tingkat pendidikan dengan kehamilan usia kehamilan remaja $(\mathrm{p}=0,001)$. dini dengan nilai $\mathrm{p}=0,003$ dan $\mathrm{OR}=3,857$, artinya Menurut asumsi peneliti pendidikan responden dengan pendidikan rendah berpeluang 4 yang tinggi akan meningkatkan pengetahuan dan kali untuk mengalami kehamilan di usia dini jika pemahaman ibu terhadap suatu masalah atau dibandingkan dengan responden yang informasi, termasuk masalah kehamilan di usia berpendidikan tinggi.

Hasil penelitian ini sejalan dengan akan mengetahui dan memahami tentang manfaat penelitian yang telah dilakukan oleh Dwinanda, serta resiko kehamilan di usia dini, sehingga ibu dkk (2015) dengan judul Hubungan antara cenderung akan berusaha melakukan yang terbaik pendidikan ibu dan pengetahuan dengan yaitu menghindari untuk menjalani kehamilan di pernikahan usia dini di Kecamatan Plaosan usia dini.

\section{b Hubungan Perilaku dengan Kehamilan Usia Dini}


Hubungan Perilaku dengan Kehamilan Usia Dini di Wilayah Kerja Puskesmas Guguk Panjang

\begin{tabular}{|c|c|c|c|c|c|c|c|c|c|}
\hline \multirow{3}{*}{$\begin{array}{l}\mathbf{N} \\
\mathbf{0}\end{array}$} & \multirow[t]{3}{*}{ Perilaku } & \multicolumn{6}{|c|}{ Kehamilan Usia Dini } & \multirow{3}{*}{$\begin{array}{l}\text { pv } \\
\text { alu } \\
\text { e }\end{array}$} & \multirow{3}{*}{$\begin{array}{l}\text { OR } \\
\text { (95\% } \\
\text { CI) }\end{array}$} \\
\hline & & \multicolumn{2}{|c|}{ Ada } & \multicolumn{2}{|c|}{ Tidak } & \multicolumn{2}{|c|}{ Total } & & \\
\hline & & $\mathrm{n}$ & $\%$ & $\mathrm{n}$ & $\%$ & $\mathrm{~N}$ & $\%$ & & \\
\hline 1 & Negatif & 33 & 63 , & 19 & 36,5 & 52 & 100 & 0,0 & 3,821 \\
\hline 2 & Positif & 15 & $\begin{array}{l}5 \\
31, \\
3\end{array}$ & 33 & 68,8 & 48 & 100 & 03 & $\begin{array}{l}(1,66 \\
48,77 \\
)\end{array}$ \\
\hline & Jumlah & 48 & 48 & 52 & 52 & 100 & 100 & & \\
\hline
\end{tabular}

Berdasarkan tabel 6 diketahui bahwa dari 52 orang responden dengan perilaku negatif, terdapat lebih dari sebahagian $(63,5 \%)$ responden dengan kehamilan usia dini. Sedangkan dari 48 orang responden dengan perilaku positif, kurang dari sebahagian (31,3\%) responden dengan kehamilan usia dini. Hasil analisis statistik menunjukkan bahwa ada hubungan antara perilaku dengan kehamilan $\mathrm{n}$ usia dini dengan nilai $\mathrm{p}=0,003$ dan $\mathrm{OR}=$ 3,821 artinya responden dengan perilaku negatif berpeluang 4 kali untuk menjalani kehamilan di usia muda jika dibandingkan responden dengan perilaku positif.

Hasil penelitian menunjukkan bahwa lebih dari sebahagian $(52 \%)$ responden dengan kategori perilaku negatif yaitu perilaku yang beresiko terhadap kehamilan di usia dini. Sedangkan sisanya sebanyak $48 \%$ adalah ibu hamil dengan kategori perilaku positif.

Menurut asumsi peneliti di

Wilayah Kerja Puskesmas Guguk Panjang masih banyak ditemukan masyarakatnya yang berperilaku negatif yaitu perilaku yang beresiko untuk menjalani kehamilan di usia dini, dimana masih banyak ditemukan masyarakatnya khususnya remaja yang memiliki perilaku yang beresiko terhadap kehamilan usia dini, yaitu perilaku seks pada usia dini, seperti berpacaran, berpelukan atau bahkan berhubungan seksual di usia yang cenderung terlalu muda. Hal ini terlihat dari hasil observasi dan kuisioner penelitian dimana sebagian besar ibu mulai berpacaran sejak usia sekolah yaitu SMP, SMA usia dini, yaitu perilaku seks pada usia dini, seperti bahkan sudah ada yang berpacaran mulai dari bangku Sekolah Dasar. Hal ini tentulah tidak baik, karena berpacaran merupakan salah satu tindakan yang mengarah pada seks usia dini jika tidak mendapat pengawasan yang tepat dari orang tua, guru atau masyarakat.

\section{c Hubungan Sosial Budaya dengan Kehamilan Usia Dini}

Tabel 7

Hubungan Sosial Budaya dengan Kehamilan Usia Dini di Wilayah Kerja Puskesmas Guguk Panjang

\begin{tabular}{llrrrrrrr}
\hline \multirow{2}{*}{ No } & Media & \multicolumn{6}{c}{ Kehamilan Usia Dini } \\
\cline { 3 - 8 } & & \multicolumn{2}{c}{ Ada } & \multicolumn{2}{c}{ Tidak } & \multicolumn{2}{c}{ Total } \\
\cline { 3 - 8 } & & $\mathrm{n}$ & $\%$ & $\mathrm{n}$ & $\%$ & $\mathrm{~N}$ & $\%$ \\
\hline $\mathbf{1 .}$ & Terpengaruh & 42 & 56 & 33 & 44 & 75 & 100 \\
$\mathbf{2 .}$ & 6 & 24 & 19 & 76 & 25 & 100 \\
& Tidak & Terpengaruh & & & & & & \\
\hline & Jumlah & 48 & 48 & 52 & 52 & \multicolumn{1}{c}{10} & 100 \\
\hline
\end{tabular}

Berdasarkan tabel 7 diketahui bahwa dari 38 orang responden dengan sosial budaya tidak baik, terdapat lebih dari sebahagian $(65,8 \%)$ dengan kehamilan di usia dini. Sedangkan dari 62 orang responden dengan sosial budaya baik, terdapat kurang dari sebahagian $(37,1 \%)$ responden dengan kehamilan di usia dini. Hasil analisis statistik menunjukkan bahwa ada hubungan antara sosial budaya dengan kehamilan usia dini dengan nilai $\mathrm{p}=0,01$ dan $\mathrm{OR}=3,261$.

Hasil penelitian menunjukkan bahwa lebih dari sebahagian (62\%) ibu hamil dengan lingkungan sosial budaya positif, yaitu lingkungan sosial budaya yang memberikan nilai-nilai dan norma yang positif terhadap perkembangan dan perilaku masyarakat, khususnya norma yang mengatur tentang kehamilan usia dini. Hasil penelitian ini sejalan dengan penelitian yang telah dilakukan oleh Anesia dan Notobroto (2013) dengan judul Faktor yang Memengaruhi Perilaku Seksual Pranikah Remaja yang Bertunangan didapatkan hasil bahwa $75 \%$ responden dengan perilaku seksual negatif yaitu berpelukan dan berciuman. 
Menurut asumsi peneliti di Wilayah Kerja Puskesma Guguk Panjang masih banyak ditemukan masyarakatnya yang berperilaku negatif yaitu perilaku yang beresiko untuk menjalani kehamilan di usia dini, dimana masih banyak ditemukan masyarakatnya khususnya remaja yang memiliki perilaku yang beresiko terhadap kehamilan usia dini, yaitu perilaku seks pada usia dini, seperti berpacaran, berpelukan atau bahkan berhubungan seksual di usia yang muda.

\section{d Hubungan Media Massa dengan Kehamilan Usia Dini}

Tabel 8

Hubungan Media Massa dengan Kehamilan Usia Dini di Wilayah Kerja Puskesmas Guguk Panjang

\begin{tabular}{|c|c|c|c|c|c|c|c|c|c|}
\hline \multirow{3}{*}{$\begin{array}{l}\mathbf{N} \\
\mathbf{o}\end{array}$} & \multirow{3}{*}{$\begin{array}{l}\text { Sosial } \\
\text { Buday } \\
\text { a }\end{array}$} & \multicolumn{4}{|c|}{ Kehamilan Usia Dini } & \multirow{2}{*}{$\begin{array}{l}P \\
\text { val } \\
\text { ue }\end{array}$} & \multirow{2}{*}{\multicolumn{2}{|c|}{$\begin{array}{l}\text { OR } \\
(95 \% \text { CI })\end{array}$}} & \\
\hline & & \multicolumn{2}{|c|}{ Ada } & \multirow{2}{*}{$\begin{array}{l}\text { Tida } \\
\mathrm{k} \\
\mathrm{n}\end{array}$} & Total & & & & \\
\hline & & $\mathrm{n}$ & $\%$ & & $\%$ & $\mathrm{~N}$ & $\%$ & & \\
\hline 1 & $\begin{array}{l}\text { Tidak } \\
\text { baik }\end{array}$ & 25 & $\begin{array}{l}65, \\
8\end{array}$ & 13 & 34,2 & 38 & $\begin{array}{l}10 \\
0\end{array}$ & 0,0 & $\begin{array}{l}3,261 \\
(1,4007,59\end{array}$ \\
\hline \multirow[t]{2}{*}{2} & Baik & 23 & $\begin{array}{l}37, \\
1\end{array}$ & 39 & 62,9 & 62 & $\begin{array}{l}10 \\
0\end{array}$ & 10 & 4) \\
\hline & Jumlah & 48 & 48 & 52 & 52 & $\begin{array}{l}10 \\
0\end{array}$ & $\begin{array}{l}10 \\
0\end{array}$ & & \\
\hline
\end{tabular}

Berdasarkan tabel 8 diketahui bahwa dari 75 orang responden beresiko terpengaruh media masa, terdapat lebih dari sebahagian (56\%) responden dengan kehamilan di usia dini. Sedangkan dari 25 orang responden yang tidak beresiko terpengaruh dari media massa, hanya sebagian kecil (24\%) responden dengan kehamilan di usia dini. Hasil analisis statistik menunjukkan bahwa ada hubungan antara media massa dengan kehamilan usia dini dengan nilai $\mathrm{p}=0,011$ dan $\mathrm{OR}=4,030$, artinya responden yang beresiko terpengaruh media massa berpeluang 4 kali untuk menjalani kehamilan di usia muda jika dibandingkan dengan responden yang tidak beresiko terpengaruh dari media massa.

Hasil penelitian menunjukkan bahwa lebih sebagian besar $(75 \%)$ ibu beresiko terpengaruh oleh media massa, yaitu ibu-ibu yang kurang memiliki kontrol untuk mengakses media massa, seperti internet dan televisi. Berdasarkan hasil sebaran kuisioner diketahui bahwa pengaruh penggunaan media massa paling banyak dilakukan ibu adalah secara keseluruhan ibu memiliki akun media sosial (facebook, twitter dan instan gram, line), keseluruhan ibu (100\%) menyatakan paling banyak memperoleh informasi dari televisi dan media sosial, dan $99 \%$ ibu menyatakan bahwa sering menonton televisi dan 53\% ibu menyatakan sering mengikuti tren yang disajikan oleh media massa. Sedangkan pengaruh media massa yang paling kecil adalah kebiasaan ibu dalam membaca koran dan majalah hanya sebesar $18 \%$ ibu yang memiliki kebiasaan mengakses informasi dari koran atau majalah.

Hasil penelitian ini sejalan dengan penelitian yang telah dilakukan oleh Murti (2008) dengan judul Hubungan antara frekuensi paparan pornografi melalui media massa dengan tingkat perilaku seksual pada siswa SMU Muhammadiyah 3 , didapatkan hasil bahwa 50,7\% remaja dengan paparan tinggi terhadap pornografi melalui media massa.

Menurut asumsi peneliti pada saat ini media massa memberikan pengaruh yang tinggi terhadap setiap aspek kehidupan masyarakat, terutama pada kelompok usia muda, dimana dengan kemajuan ilmu pengetahuan dan teknologi hampir seluruh lapisan masyarakat memiliki akses yang mudah terhadap kebutuhan informasi, terutama informasi yang disediakan di televisi dan internet.

\section{SIMPULAN}

\section{A.Kesimpulan}

Berdasarkan hasil penelitian dan pembahasan tentang Faktor-faktor yang berhubungan dengan kehamilan usia dini Wilayah Kerja Puskesmas Guguk Panjang Tahun 2016 dapat disimpulkan bahwa sebanyak $60 \%$ responden berpendidikan tinggi, $57 \%$ responden dengan status ekonomi tinggi, 52\% responden dengan perilaku negatif, $62 \%$ responden dengan sosial budaya baik, $75 \%$ responden beresiko terpengaruh oleh media massa dan $52 \%$ responden tidak menjalani kehamilan usia dini. Ada hubungan pendidikan dengan kehamilan usia dini, secara statistik didapatkan nilai $p=0,003$ dan $\mathrm{OR}=3,857$, ada hubungan ekonomi dengan kehamilan usia dini, secara statistik didapatkan nilai $\mathrm{p}=0,018$ dan $\mathrm{OR}$ 
$=2,893$, ada hubungan perilaku dengan kehamilan usia dini, secara statistik didapatkan nilai $\mathrm{p}=0,003$ dan $\mathrm{OR}=$ 3,821 , ada hubungan sosial budaya dengan kehamilan usia dini, secara statistik didapatkan nilai $\mathrm{p}=0,01$ dan $\mathrm{OR}=3,261$ dan ada hubungan media massa dengan kehamilan usia dini, secara statistik didapatkan nilai $\mathrm{p}=0,011$ dan $\mathrm{OR}=4,030$

\section{B.Saran}

\section{Bagi Responden}

Diharapkan kepada responden khususnya ibu hamil untuk selalu meningkatkan pemahaman dan pengetahuan ibu tentang kehamilan, khususnya usia yang ideal untuk menjalani kehamilan melalui berbagai sumber informasi terpercaya salah satunya adalah melalui tenaga kesehatan dengan mengikuti setiap sosialisasi dan penyuluhan yang diberikan oleh tenaga kesehatan, Agar pengetahuan ibu dapat ditingkatkan dan ibu dapat merencanakan sebuah kehamilan yang tidak beresiko yaitu antara $20-35$ tahun.

\section{Bagi Institusi Pendidikan}

Diharapkan kepada pihak
institusi pendidikan untuk dapat
meningkatkan bimbingan dan
pemahaman kepada peserta didiknya,
khususnya tentang kesehatan reproduksi
wanita melalui berbagai program-
program khususnya yang membahas
tentang kesehatan reproduksi. Agar
pengetahuan peserta didik dapat
ditingkatkan serta termotivasi untuk
menghindari kehamilan usia dini.

\section{Bagi Peneliti Selanjutnya}

Diharapkan kepada peneliti untuk dapat melakukan penelitian lebih lanjut tentang faktor-faktor yang berhubungan dengan kehamilan usia dini dengan variabel yang berbeda yang tidak menjadi bahasan dalam penelitian ini.

\section{UCAPAN TERIMA KASIH}

Terima kasih kepada segenap jajaran Puskesmas Guguk Panjang atas dukungan dalam penelitian ini, serta responden yang telah ikut berartisipasi dalam melakukan penelitian. Selanjutnya, terima kasih kepada Institusi dan rekan-rekan yang telah memberi saran dan masukan atas penelitian ini, sehingga penelitian ini dapat digunakan untuk penelitian selanjutnya.

\section{REFERENSI}

Agustina, 2015. Faktor sosial budaya yang mempengaruhi pernikahan dini pada remaja usia 15-19 tahun di kelurahan martubung kecematan medan labuhan di akses tanggal 20 september 2016

Arikunto, 2003.Metodologi Penelitian. Semarang: Erlangga.

Badan pusat statistik, 2012. https://BPS.com/kehamilanusiadini/diakses pada tanggal 4 maret 2016

BKKBN, 2014. Data kehamilan usia remajahttp://bkkbn.co.iddi akses tanggal 10 februari 2016

Budiarto, Eko, 2002. Biostatistik untuk Kedokteran dan Kesehatan Masyarakat Dalam: Arlinda Sari Wahyuni. 2007. Statistika Kedokteran.

Cangara, Hafied. 2003. Pengantar Ilmu komunikasi. Jakarta: PT Raja Grafindo Persada.

Dwinanda, dkk, 2015. Dalam hubungan antara penidikan ibu dan pengetahuan dengan pernikahan usia dini di kecamatan plaosan di akses tanggal 20 september 2016

Efendy,U.Onong. 2008. Selebaran atau

Leaflet.http://inoz3ro.blogspot.com/ 2008/09/selebaran-atauleafletadalah-lembaran.html Di akses 23 maret 2016

Firza, 2011.Hubungan perilaku seksual dengan

pernikahan usia dini pada remaja didesa karang duwakkecamatan 
arosbaya.Di akses tanggal 20 september 2016

Hidayat, 2011.Metode Penelitian Dan Teknik Analisa Data. Jakarta: salemba medika

Latifah, Lutfatul. 2010. Hubungan kehamilan pada usia remaja dengan kejadianPrematuritas, berat bayi lahir rendah dan asfiksia. Diakses pada tanggal 8 maret 2016

Liliweri, Alo. 2007. Dasar-dasar Komunikasi

Kesehatan. Yogyakarta: Pustaka

Manuaba, Gede Bagus Ida. 2012. Buku Ajar

Pengantar Kuliah : Teknik Operasi Obstetri \& Keluarga

Berencana.Jakarta: Trans Info Media

Nguyen, 2016. Prevalence and factors assiscated with teen pregnancy in Vietnam.Diakses tanggal 20 september 2016

Notoatmodjo, Soekidjo. 2012. Metodologi Penelitian Kesehatan. Jakarta: Rineka Cipta

Notoatmodjo, Soekidjo. 2003. Metodologi Penelitian Kesehatan. Jakarta: Rineka Cipta

Profil Kesehatan Indonesia. 2014. http://profilkesehatanIndonesia2014 .pdfDiakses pada tanggal 18 Januari 2016.

Purwanto,Effy.2009.Pengantar World WideWeb.http://www.litbang.depkes .go.id/tik/media/Pengantar_

WWW.doc. Di akses 23 maret 2016.

Rivers, William L. 2003. Media Massa \& Masyarakat Modern. Jakarta: Prenada Media.

Rochjati, P., 2003. Skrining Antenatal Pada Ibu Hamil. Surabaya: FK UNAIR

Rostina. 2008. Definisi Kesehatan Reproduksi Remaja. http://www.kesrepro.info/?q=node/ 380di akses 21 maret 2016.

Santrock, John W. 2003. Adolescence Perkembangan Remaja. Jakarta: Erlangga

Sugiharta, 2004. Faktor-faktor yang mempengaruhi prilaku siwi sma $x$ terhadap kesehatan reproduksi tahun 2012. Diakses pada tanggal 6 maret 2016.

Supranto. 2001. Statistik Teori dan Aplikasi Edisi Keenam. Jakarta: Erlangga.

Sutisna, Senjaya. 2009. Pendidikan Media Massa.

www.sutisna.com/pendidikan/media massa-3. di akses 21 maret 2016

Ubaydillah, 2000.Referensi Kesehatan. https://creasoft.wordpress.com/2008 /04/23/resiko-tinggi-kehamilanremaja-usiamuda/

WHO, 2012. Kejadian kehamilan usia dini di dunia http://www.agiusa.org/pubs/newswo rld_indo.html. Di akses pada tanggal 4 maret 2016

Wilopo, 2005. Dalam jurnal bahaya kehamilan usia dini. Diakses tanggal 6 maret 2016

Zuhri, Amin, 2009. Pengaruh pendidikan kesehatan reproduksi terhadap tingkat pengetahuan mengenai kehamilan dan persalinan usia dini pada remaja putri SMA muhamadiyah Gubug tahun 2009 diakses pada tanggal 18 februari 2016 